\title{
Impact of Aurelia aurita medusae (Cnidaria, Scyphozoa) on the standing stock and community composition of mesozooplankton in the Kiel Bight (western Baltic Sea)
}

\author{
G. Behrends ${ }^{1, *}$, G. Schneider ${ }^{2}$ \\ ${ }^{1}$ Institut für Meereskunde, Düsternbrooker Weg 20, D-24105 Kiel, Germany \\ ${ }^{2}$ Biologische Anstalt Helgoland, Hafenstraße 46, D-25989 List/Sylt, Germany
}

\begin{abstract}
During 5 consecutive summer seasons (1990 to 1994) both Aurelia aurita medusa and mesozooplankton abundances were investigated at 2 stations in the Kiel Bight (western Baltic Sea). Stocks of medusae varied considerably between the years, with median abundance of 1 and 0.3 ind. $100 \mathrm{~m}^{-3}$ in 1990 and 1991,3 and 4 nd. $100 \mathrm{~m}^{-3}$ in 1992 and 1994 , but 9 ind $100 \mathrm{~m}^{-3}$ in 1993 . Significant differences in the mesozooplankton stock and community composition were observed in 1993 when compared with the year of rather low Aurelia abundance (1991). Total zooplankton and copepod numbers both exhibited an inverse relationship with the abundance of medusae and were thus considerably lower in 1993 than in 1991 However, not all copepod species were affected by A. aurita. Pseudo- and Paracalanus spp. and Oithona similis showed dramatically reduced stocks in the bloom year when compared with the medusa-poor situation, but no significant changes were found for Centropages hamatus and Acartia spp. Also other zooplankton groups with the exception of bivalve larvae were reduced by the medusae. The differential response of zooplankton to varying abundance of medusae led to a shift in the trophic structure of the zooplankton community. Fine-filter feeders and raptorial feeders were much more important in years when medusae occurred in low densities, whereas coarse-filter feeders dominated in the opposite situation.
\end{abstract}

KEY WORDS: Aurelia aurita - Mesozooplankton - Predation - Kiel Bight

\section{INTRODUCTION}

Numerous studies have focused on the predatory role of gelatinous organisms in marine plankton communities (e.g. Alldredge 1984, Purcell 1985 and references therein) and it is generally accepted that their population consumption can be high when these organisms occur in sufficient numbers. Since collapses of zooplankton populations at certain times and inverse relationships between jellyfish biomass or number and zooplankton standing stock were observed in various areas, these phenomena were consequently assumed to be due to control by gelatinous predators (e.g.

·E-mail: gbehrends@ifm.uni-kiel.d400.de
Huntley \& Hobson 1978, Deason \& Smayda 1982, Feigenbaum \& Kelly 1984, Panayotidis et al. 1988, García 1990, Matsakis \& Conover 1991, Purcell 1992).

This may also apply for the Kiel Bight (western Baltic Sea). In this area a pronouced annual cycle of zooplankton standing stock is described in many papers (Lohmann 1908, Hillebrandt 1972. Martens 1976, Schnack 1978, Smetacek 1980). During winter and early spring zooplankton standing stock is low, but a mass development of mesozooplankton usually occurs in May. This bloom is primarily due to copepods, of which 2 species dominate: Pseudocalanus minutus elongatus and Oithona similis. Additionally meroplanktic larvae increase significantly with bivalve offspring contributing more than two-thirds of all larvae. 
This bloom, however, is terminated abruptly in June with a sharp drop in copepod abundance and, to a lesser extent, meroplanktic larvae. On the whole, zooplankton abundance remains low during June, July and early August but peaks again in autumn. However - and more important in the context of this paper pronounced interannual variation was observed for summer zooplankton biomass with rather high standard deviations between years occurring in June and July (Hillebrandt 1972).

It has been suggested (e.g. Möller 1978/79, 1980), that this decline in zooplankton biomass during summer and especially the large interannual variation is due to predation by the scyphomedusa Aurelia aurita. This species, indeed, develops in May and reaches its peak population biomass in June or early July (Möller 1980, Schneider 1989a). However, considerably interannual variation was observed for this species, too (Schneider \& Behrends 1994), so that bloom years and years with low population densities can be distinguished. Due to their carnivorous mode of feeding and the finding that in the Kiel Bight $A$. aurita medusae also accept all kinds of zooplankton as food (Kerstan 1977), the predation hypothesis (Paine 1966) appears to be the most likely explanation. Reduction of zooplankton, however, may lead to changes in lower trophic levels, so that $A$. aurita as a top-predator may perhaps induce trophic cascading (Carpenter et al. 1985), thus regulating the whole plankton system.

In this paper, we present data from a 5 year investigation (1990 to 1994), which compared zooplankton standing stock and Aurelia aurita occurrence with the ultimate goal of determining whether or not variations of medusae stocks are responsible for interannual variation of zooplankton abundance and species composition.

\section{MATERIAL AND METHODS}

Aurelia aurita samples were obtained monthly at 2 stations in the Kiel Bight (Fig. 1) during summer (June to September) 1990 to 1994 . Oblique hauls as close to the sea-bed as possible were carried out at each station with a bongo-net fitted with a 300 and a $500 \mu \mathrm{m}$ gauze. Generally, 100 to $200 \mathrm{~m}^{3}$ of water was filtered. The medusae caught were counted and their diameter measured to the $\mathrm{cm}$ as described by Moller (1980). At the same stations and cruises, mesozooplankton was sampled by means of a WP-2 net with a $100 \mu \mathrm{m}$ gauze in vertical hauls from $5 \mathrm{~m}$ above the sea-bed to the surface. The samples were preserved with $4 \%$ formalin buffered with borax and were counted later in the laboratory. Meroplankton was determined at group level (bivalve larvae, polychaete larve etc.), other zooplank-

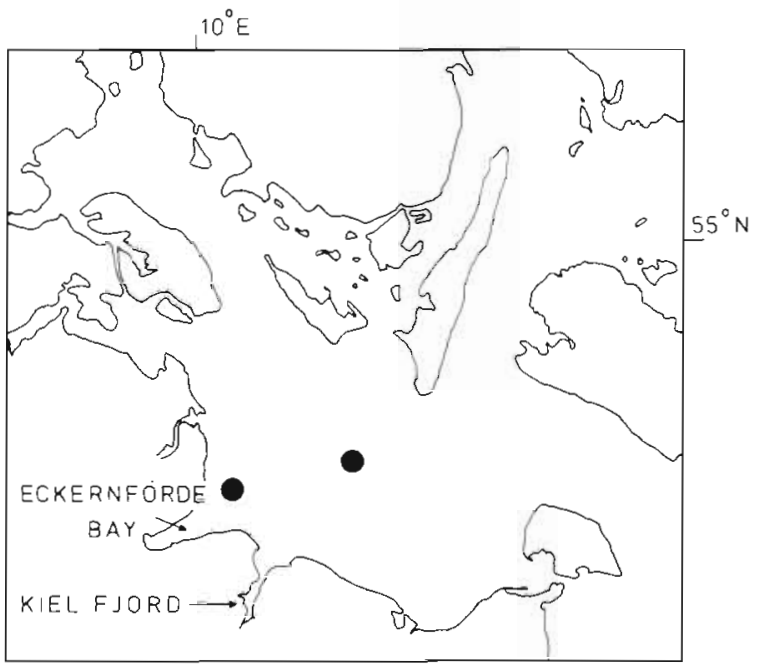

Fig. 1. Map of the Kiel Bight with dots indicating sampling stations

ton at species level. In the case of Pseudocalanus minutus elongatus and Paracalanus parvus, the young copepodite stages (C I to III) could not be separated. Therefore, in this paper the 2 species are treated together as Pseudo- and Paracalanus spp. The 4 Acartia species occurring in the Kiel Bight were also pooled because some of these species occasionally occurred in rather low numbers

Prior to further statistical treatment, all data sets were tested for deviation from the normal distribution by means of the Kolmogorov-Smirnoff test. Significant deviations were detected for the Aurelia data in 1990 and for the data of Pseudo- and Paracalanus spp. obtained in 1993 ( $\mathrm{Dk}=0.455$ and 0.569 respectively). Thus, parameter-free methods were used for all calculations. The data sets are described either by the median, the range covering $50 \%$ of all data and the total range, or the median \pm median deviation. For comparison between years, the Kruskal-Wallis test for homogeneity was performed. In case of rejection of the $\mathrm{H}_{0}$ hypothesis $\left(\mu_{1}=\mu_{2}=\mu_{3}=\ldots\right)$, a Nemenyi test was carried out to determine the significant different data sets. All calculations were carried out with the aid of the STATEASY computer programme (Lozan 1993).

\section{RESULTS}

The 5 summer seasons investigated represented different situations with respect to Aurelia aurita abundance. Both in 1990 and 1991 population stocks were rather low (Fig. 2), with abundance ranging between 0 and 4.4 medusae $100 \mathrm{~m}^{-3}$ and median values of 1.0 and 0.3 ind. $100 \mathrm{~m}^{-3}$. In 1992, abundance was generally higher averaging 3.4 medusae $100 \mathrm{~m}^{-3}$ but maximum 


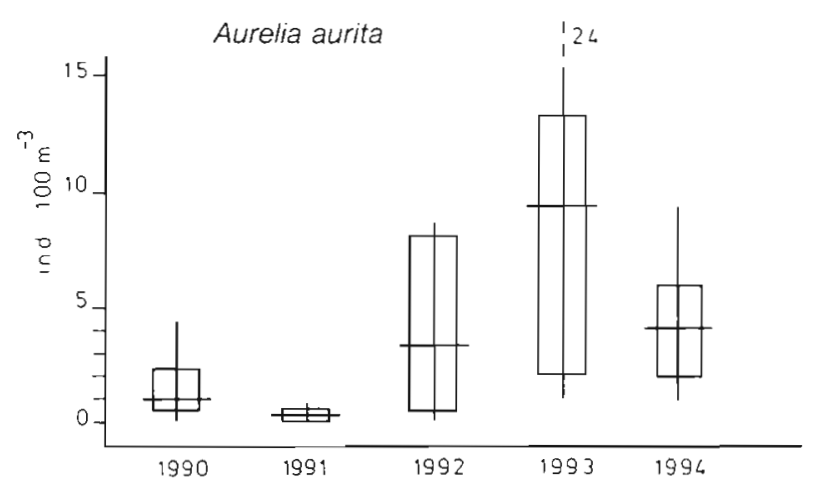

Fig. 2. Box-Whisker plots of Aurelia aurita abundance during summer 1990 to 1994 . Vertical lines give total range, horizontal lines indicate the median value and boxes show the range of $50 \%$ of all data (between upper and lower quartiles). Number of data: 1990: $\mathrm{n}=6 ; 1991: \mathrm{n}=6 ; 1992: \mathrm{n}=7 ; 1993: \mathrm{n}=7$; 1994: $n=8$

values were observed in 1993 with up to 24 medusae 100 $\mathrm{m}^{-3}$ and a median of 9 ind. $100 \mathrm{~m}^{-3}$. Finally, in 1994 the population density was similar to that in 1992 with a median value of 4.2 ind. $100 \mathrm{~m}^{-3}$. Thus, 1990 and 1991 represented years with low abundance, 1992 and 1994 were intermediate and 1993 was obviously a bloom year. Testing for significant differences (Table 1) revealed statistical significance between 1991 and 1993. The intermediate data of 1990, 1992 and 1994 did not differ significantly from those obtained during 1991 and 1993.

Total zooplankton numbers were inversely related to Aurelia abundance (Fig. 3A). In 1991 median abundance of total zooplankton was highest, but lowest in 1993, the bloom year of Aurelia aurita. Significance was achieved for these 2 years (Table 1 ). The results of 1990, 1992 and 1994 were intermediate between the significant end-points, thus indicating the trend of declining zooplankton abundance with increasing median abundance of medusae. The same result was obtained for the copepod fraction (Fig. 3B) but not for bivalve larvae (Fig $3 \mathrm{C}$ ), which showed no significant trend with increasing population density of the
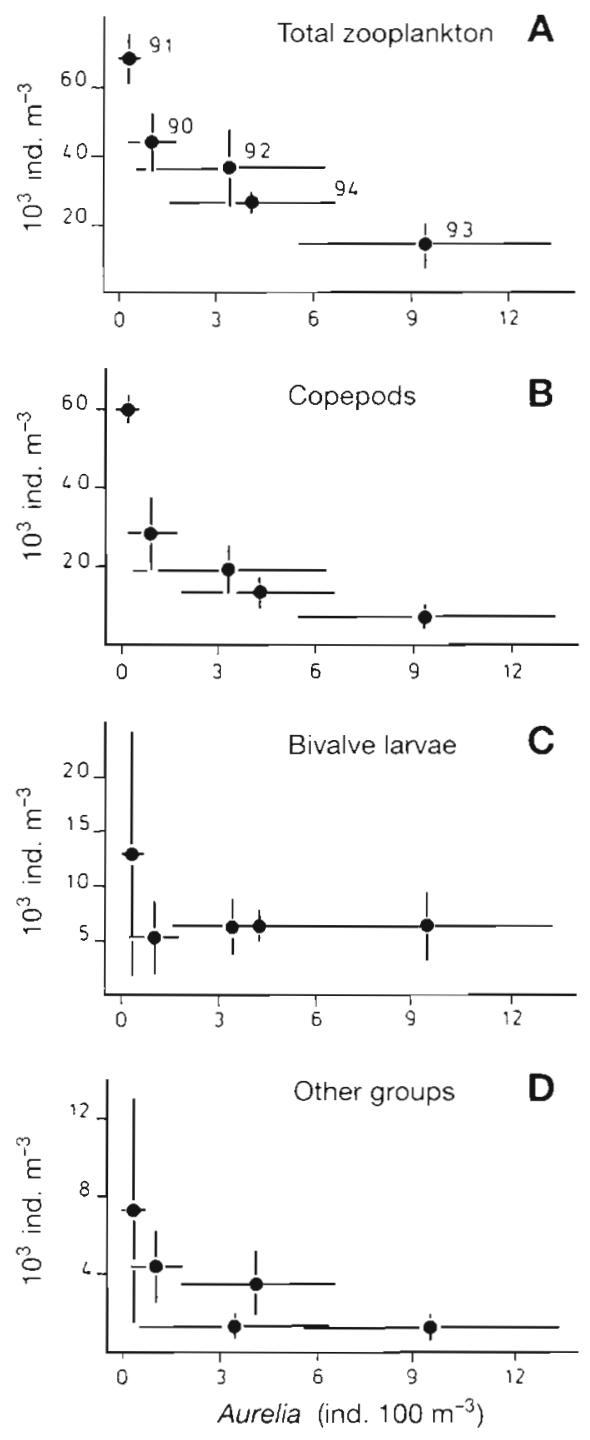

Fig. 3. Average abundance (median \pm median deviation) of (A) total zooplankton, (B) copepods, (C) bivalve larvae and (D) 'other groups' plotted against average abundance of Aurelia aurita medusae in the different summer seasons investigated. Numbers in (A) denote years

Table 1. Results of the Kruskal-Wallis test for homogeneity $\left(\mathrm{H}_{0}: \mu_{1990}=\mu_{1991}=\ldots=\mu_{1994}\right)$ and Nemenyi test if $\mathrm{H}_{0}$ was rejected. a: accepted; r: rejected

\begin{tabular}{|c|c|c|c|c|c|}
\hline Data set & $\mathrm{H}$ & $\mathrm{p}$ & $\mathrm{H}_{0}$ & Nemenyi & Difference \\
\hline Aurelia aurita & 13.598 & 0.0087 & r & 18.04 & 1991 vs 1993 \\
\hline Total zooplankton & 11.065 & 0.0026 & $\mathrm{r}$ & 20.80 & 1991 vs 1993 \\
\hline Copepods & 18.722 & 0.0009 & $\mathrm{r}$ & 20.46 & 1991 vs 1993 \\
\hline Bivalve larvae & 1.932 & 0.7483 & a & & \\
\hline Other groups & 7.510 & 0.1113 & a & & \\
\hline Pseudo- and Paracalanus & 17.167 & 0.0018 & r & $18.43,17.17$ & 1991 vs 1993,1991 vs 1994 \\
\hline Oithona similis & 19.236 & 0.0007 & $\mathrm{r}$ & $13.49,17.03$ & 1991 vs 1993.1991 vs 1994 \\
\hline Centropages hamatus & 2.080 & 0.7210 & a & & \\
\hline Acartia spp. & 4.873 & 0.3006 & a & & \\
\hline
\end{tabular}



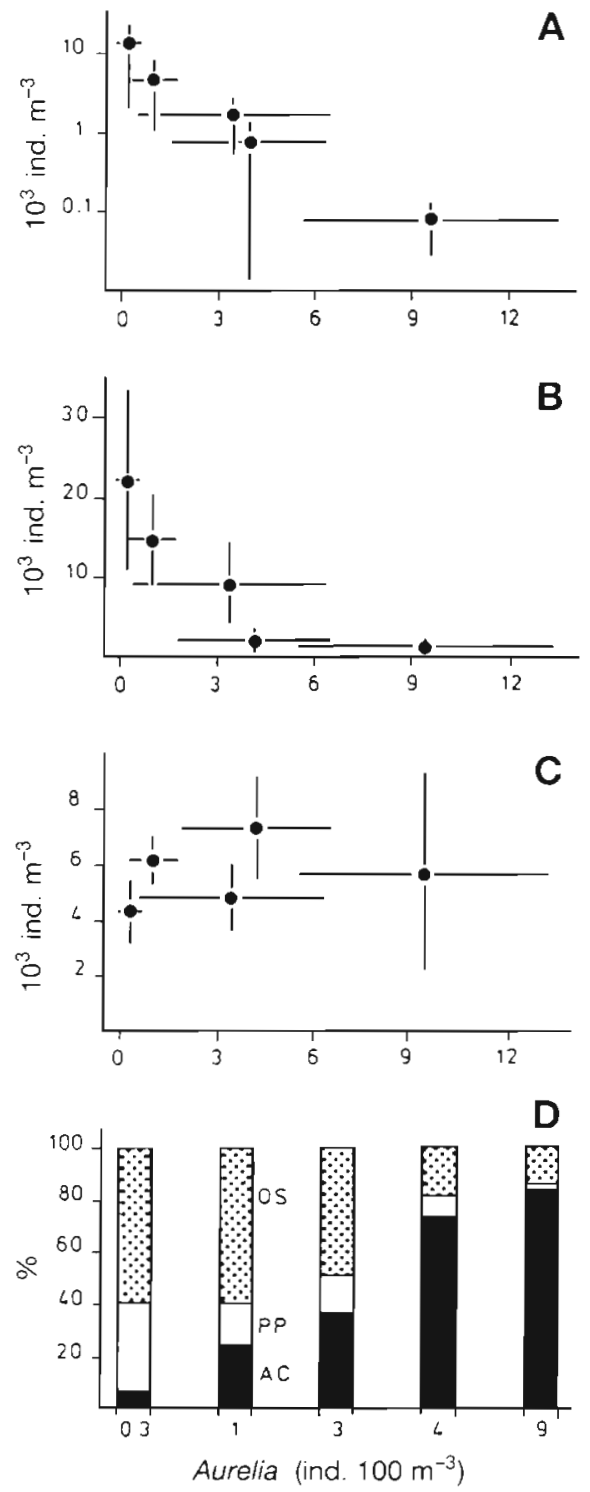

Fig. 4. Average abundance of (A) Pseudo- and Paracalanus spp., (B) Oithona similis and (C) Centropages hamatus + Acartia spp. plotted against average abundance of Aurelia aurita medusae. Note logarithmic scale of $y$-axis in (A). (D) Relative proportion (\%) of the different copepods in relation to increasing abundance of medusae. OS: $O$. similis; PP. Pseudo- and Paracalanus spp.; AC: Acartia spp. + C. hamatus

medusae. The 'other groups' (representing cladocerans, chaetognaths, polychaete and gastropod larvae, appendicularians etc.) exhibited the same trend as observed for total zooplankton and the copepods (Fig, 3D) but without a significant result (Table 1).

Within the copepod fraction a different pattern was obtained for the species investigated. Both Pseudo- 1 Paracalanus spp. and Oithona similis appeared to be rather affected by increasing abundance of medusae
(Fig. 4A, B), whereas Centropages hamatus and Acartia spp. median abundances were more or less the same in the 5 summers studied (Fig. 4C, Table 1). Therefore, a shift in the relative copepod species composition was observed (Fig. 4D): more than 90\% of all copepods in 1991 were formed by Pseudo-/Paracalanus and Oithona whereas in 1993 these 2 'species' made up only about $20 \%$. Consequently, the share of $C$. hamatus + Acartia spp. has increased dramatically from approximately 10 to $80 \%$.

Summarizing these findings, it can be concluded that the stocks of most zooplankton species will be negatively affected by medusae populations. However, this was not observed for bivalve larvae and the 2 copepods generally accepted to be typical summer species in the Kiel Bight.

\section{DISCUSSION}

The results have shown that zooplankton abundance in the Kiel Bight is significantly lower during years rich in medusae than in years with low medusa stocks. This seems to confirm the predation hypothesis mentioned above. Feeding experiments with Aurelia aurita medusae carried out by Kerstan (1977) revealed individual ingestion rates between 800 and 8000 Artemia nauplii $\mathrm{h}^{-1}$, corresponding with 6 to $75 \mathrm{mg} \mathrm{C}$ medusa $^{-1}$ $\mathrm{d}^{-1}$ when assuming a feeding period of $16 \mathrm{~h} \mathrm{~d}^{-1}$ and a carbon content of $0.6 \mu \mathrm{g}$ nauplius ${ }^{-1}$ (Paffenhöfer 1967. Platt et al. 1969). The overall mean of $40 \pm 17 \mathrm{mg} \mathrm{C}$ medusa ${ }^{-1} \mathrm{~d}^{-1}$ suggests a high predation potential when compared with the average carbon weight of $4 \mu \mathrm{g} \mathrm{C}$ ind.$^{-1}$ measured by Martens (1976) for copepods in the Kiel Bight (approx. 10000 copepods medusa ${ }^{-1} \mathrm{~d}^{-1}$ ). Estimates of minimum carbon ingestion rates to satisfy at least metabolism and growth of the medusae revealed similar results ( 40 to $50 \mathrm{mg} \mathrm{C}$ medusa $^{-1} \mathrm{~d}^{-1}$ ). It was concluded that in bloom years populations of medusae may consume about two-thirds of daily secondary production (Schneider 1989b, Schneider \& Behrends 1994). These estimated rates are similar to those determined for other large scyphomedusae. Ingestion rates of Stomolophus meleagris ranged between 20 and $100 \mathrm{mg} \mathrm{C}$ medusa ${ }^{-1} \mathrm{~d}^{-1}$ (Larson 1991). Purcell (1992) measured a maximal copepod ingestion rate of 19000 ind. medusa ${ }^{-1} \mathrm{~d}^{-1}$ in Chrysaora quinquecirrha. This probably corresponds to carbon values of about 70 to $80 \mathrm{mg} \mathrm{C}$ medusa ${ }^{-1} \mathrm{~d}^{-1}$. The predation potential of scyphomedusae is therefore high but its actual role in the field depends upon the abundance of the medusae.

Alternatively, variation of zooplankton abundance can also be caused by other factors, especially food limitation (e.g. Durbin et al. 1983, Kiørboe \& Nielsen 
Table 2. Average primary production and phytoplankton stocks (median \pm median deviation) during the summer seasons examined for medusa-zooplankton relationships. PP: primary production (mg $\mathrm{C} \mathrm{m}^{-2} \mathrm{~h}^{-1}$ ); Chl a: chlorophyll a (mg $\mathrm{m}^{-3}$; PPC: phytoplankton carbon $\left(\mathrm{mg} \mathrm{m}^{-3}\right.$ ) determined via Utermöhl counting. Data from Horstmann \& Hansen (unpubl.); $\mathrm{n}=8$ to 26

\begin{tabular}{|rrrr|}
\hline Year & \multicolumn{1}{c}{ PP } & Chl $a$ & PPC \\
\hline 1990 & $135 \pm 33$ & $2.94 \pm 0.55$ & $106 \pm 58$ \\
1991 & $82 \pm 12$ & $2.40 \pm 0.17$ & $204 \pm 128$ \\
1992 & $155 \pm 21$ & $3.27 \pm 1.06$ & $302 \pm 181$ \\
1993 & $119 \pm 38$ & $3.61 \pm 0.94$ & $229 \pm 164$ \\
1994 & $146 \pm 83$ & $4.87 \pm 0.71$ & $475 \pm 370$ \\
\hline
\end{tabular}

1994, Purcell et al. 1994). Assuming that most mesozooplankton in the Kiel Bight are to a large extent dependent on phytoplankton, we have compiled data of phytoplankton standing stock and primary production measured by colleagues at the same stations and cruises mentioned in this paper. The data given in Table 2 suggest that phytoplankton carbon, chlorophyll a and primary production vary somewhat between years but do not indicate food limitation in a certain year when compared with other years. Especially when comparing the 2 extreme years with respect to zooplankton abundance, 1991 and 1993, food limitation of zooplankton in 1993 appears unlikely. The role of microzooplankton and total particulate organic carbon can not be assessed due to lack of data. Abiotic conditions, i.e temperature and salinity, did not show pronounced variation between the years 1990 and 1993, although temperature was unusually high during 1994 (up to $22^{\circ} \mathrm{C}$ ). In view of these findings it is most likely that predation by medusae was the key factor regulating zooplankton standing stock between the years of investigation.

Not all kinds of zooplankton in the Kiel Bight were, however, reduced by the medusae. Pseudo- and Paracalanus spp., Oithona similis and probably 'other groups' appear to be more vulnerable to medusae predation than Centropages hamatus, Acartia spp. and bivalve larvae. Unfortunately, we were not able to carry out gut analyses for proof of food selection in medusae. Recently, Sullivan et al. (1994) demonstrated experimentally that Aurelia aurita took up comparatively more slow swimming prey (hydromedusae, barnacle larvae) than would be expected from their abundance in the plankton. A. aurita can easily consume prey with escape velocities smaller than marginal flow velocities whereas faster prey may escape more often (Costello \& Colin 1994). These results cannot, however, explain the different response of the various species to Aurelia abundance in the Kiel Bight since escape velocities of the copepod species are unknown. Kerstan (1977) found that bivalve larvae make up a rather substantial portion of A. aurita gut contents (up to $80 \%$ of total numbers). This may be due to their slow swimming speed. Consequently, a reduction of bivalve larvae abundance in bloom years of medusae could be expected, but was not observed. We assume, therefore, similar electivity for the different copepod species but suggest that those species were not reduced by predation of medusae which are able to compensate for the losses by reproduction. Both $C$. hamatus and Acartia spp. are known to be typical summer species (Lohmann 1908, Hillebrandt 1972, Martens 1976, Schnack 1978), reproducing during this period and attaining their annual population peak during midsummer. Nevertheless, reproduction of these species will, perhaps, be slightly affected by Aurelia predation insofar as predation seems to induce a time-lag of copepod peak occurrence compared to years with poor stocks of medusae. In 1991 highest abundance of these copepods was observed in July, whereas in 1993 peak abundance was found in August; however, no significant difference in absolute values was obtained for the whole summer season. By contrast Pseudocalanus minutus elongatus do not reproduce during the summer for unknown reasons (Otten 1913) but develop and reproduce in late spring. This period coincides with the main growth season of $A$. aurita in which food demand is larger than later in summer (Schneider 1989b). Consequently, the pronounced spring peak of this copepod is suppressed in bloom years of medusae: in May and June 1991 average peak abundance of $P$. $m$. elongatus (including the smallest copepodite stages) was $30000 \pm 4000$ ind. $\mathrm{m}^{-3}$, but only $1000 \pm 700$ ind $\mathrm{m}^{-3}$ in 1993 . The reproductive cycle of $O$. similis in the Kiel Bight is not fully understood but spawning appears to occur throughout the whole summer at a moderate level, increasing sharply in autumn (Lohmann 1908). Predation by abundantly occurring medusae on adults and developmental stages of this copepod can, therefore, hinder population build-up during the summer season. In case of bivalve larvae, for which positive electivity seems probable, release of newly liberated larvae by the benthic adults may compensate the losses due to consumption by medusae. However, it is also possible that the larvae survive gut passage as observed by Purcell et al. (1991).

If we accept our results as typical, mass occurrences of Aurelia aurita will have a significant influence on the zooplankton community composition which, in turn, may perhaps induce changes in the whole food web design as is suggested in Huntley \& Hobson (1978), Deason \& Smayda (1982) and Smayda (1993). The different species of copepods in the Kiel Bight represent 3 feeding types (Schnack 1982): Pseudo- 

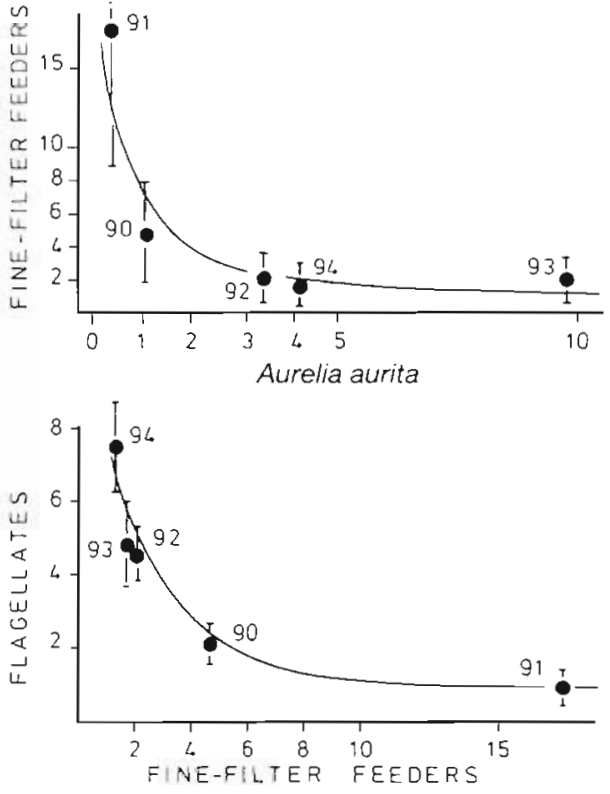

Fig. 5. Upper panel: median abundance $\left(10^{3}\right.$ ind. $\left.\mathrm{m}^{-3}\right)$ of finefilter feeders (Pseudo- and Paracalanus spp. + Oikopleura dioica) in relation to median abundance (ind. $100 \mathrm{~m}^{-3}$ ) of Aurelia aurita medusae. Lower panel: median abundance $\left(10^{6}\right.$ ind. $\left.\mathrm{l}^{-1}\right)$ of $\mu$-flagellates $(<12 \mu \mathrm{m})$ in relation to median adundance of fine-filter feeders in the different summer seasons investigated. Data of $\mu$-flagellates from Horstmann \& Hansen (unpubl.); $n=10$ to 26

calanus minutus elongatus and Paracalanus parvus are fine-filter feeders, the Acartia species and Centropages hamatus can characterized as coarse-filter feeders or omnivores, whereas Oithona similis is a raptorial predator which, however, also needs plant material (Lampitt 1978, Lampitt \& Gamble 1982). The rather low abundance of both Pseudo- and Paracalanus spp. and $O$. similis observed in the years of intermediate and high abundance of medusae led to a pronounced dominance of the coarse-filter feeders/ omnivores and only a small share of fine-filter feeders compared to the situation found in 1990/91. Additionally, another fine-filter feeding species, the appendicularian Oikopleura dioica, was much more abundant in 1991/92 (median \pm median deviation: $3000 \pm$ 1400 ind. $\left.\mathrm{m}^{-3}\right)$ than in 1992 to $1994(120 \pm 120$ ind. $\mathrm{m}^{-3}$ ). Therefore, fine-filter feeders exhibited minimum values in the years of intermediate and high abundance of medusae. Consequently, it can be expected that the smallest plankton size classes experience a higher predation pressure when fine-filter feeders like $P . m$. elongatus and $O$. dioica are abundant. It is, indeed, encouraging that the so-called $\mu$-flagellates $(<12 \mu \mathrm{m})$ were significantly less abundant in years with very low medusae abundance but high numbers of fine-filter feeding organisms when compared with the opposite situation (Fig. 5). Although other mechanisms may also explain the interannual differences of the flagellates, and the role of larger protozoans especially cannot be evaluated here, it cannot be excluded that the observed inverse relationships reflect the reduced grazing pressure by Pseudocalanus and Oikopleura which, in turn, are controlled by medusae. This speculation points to more far-reaching consequences of abundant medusoid predators than the simple reduction of zooplankton prey alone. However, experimental work is badly needed to substantiate these latter speculations.

Acknowledgements. The sampling and the shipboard measurements of the medusae were done by R. Lüthje and J. Kerstein. A. Burmeister and T Freyer supported this investigation with their skilful technical assistance. Three anonymous reviewers contributed substantially to the final version of this paper and $Y$ Henschel kindly revised the English.

\section{LITERATURE CITED}

Alldredge AL (1984) The quantitative significance of gelatinous zooplankton as pelagic consumers. In: Fasham MJR (ed) Flows of energy and materials in marine ecosystems. NATO Conf Ser [V. Mar Sci 13:407-458

Carpenter SR, Kitchell JF, Hodgson DR (1985) Cascading trophic interactions and lake productivity. BioSci 35: $634-639$

Costel.lo JH, Colin SP (1994) Morphology, fluid motion and predation by the scyphomedusa Aurelia aurita. Mar Biol $121: 327-334$

Deason EE, Smayda TJ (1982) Ctenophore-zooplanktonphytoplankton interactions in Narragansett Bay, Rhode Island, USA, during 1972-1977. J Plankton Res 4:203-217

Durbin EG, Durbin AG, Smayda TJ, Verity PG (1983) Food limitation of production by adult Acartia tonsa in Narragansett Bay, RI. Estuaries 4:24-41

Feigenbaum D, Kelly M (1984) Changes in the lower Chesapeake Bay food chain in presence of the sea nettle Chrysaora quinquecirrha (Scyphomedusae). Mar Ecol Prog Ser 19:39-47

García JR (1990) Population dynamics and production of Phyllorhiza punctata (Cnidaria: Scyphozoa) in Laguna Joyuda, Puerto Rico. Mar Ecol Prog Ser 64:243-251

Hillebrandt $M$ (1972) Untersuchungen uber die qualitative und quantitative Zusammensetzung des Zooplanktons in der Kieler Bucht während der Jahre 1966-1968. PhD dissertation, Kiel University

Huntley ME, Hobson LA (1978) Medusa predation and plankton dynamics in a temperate fjord, British Columbia. J Fish Res Bd Can 35:257-261

Kerstan M (1977) Untersuchungen zur Nahrungsókologie von Aurelia aurita Lam. MSc thesis, Kiel University

Kiørboe T, Nielsen TG (1994) Regulation of zooplankton biomass and production in a temperate, coastal ecosystem. 1 Copepods. Limnol Oceanogr 39:493-507

Lampitt RS (1978) Carnivorous feeding by a small marine copepod. Limnol Oceanogr 23:1228-1231

Lampitt RS, Gamble JC (1982) Diet and resprration of the small planktonic marine copepod Oithona nana. Mar Biol 66:185-190

Larson RJ (1991) Diet, prey selection and daily ration of Sto- 
molophus meleagris, a filter-feeding scyphomedusa from the NE Gulf of Mexico. Estuar coast Shelf Sci 32:511-525

Lohmann H (1908) Untersuchungen zur Feststellung des vollständigen Gehaltes des Meeres an Plankton. Wiss Meeresunters, Abt Kiel, NF 10:131-370

Lozán JL (1993) STATEASY Statistisches Programm für wissenschaftlıche Arbeiten. Version 2.25. Parey, Hamburg

Martens P (1976) Die planktischen Sekundär- und Tertiärproduzenten im Flachwasserökosytem der westlichen Ostsee. Kieler Meeresforsch, Sonderh 3:60-71

Matsakis S, Conover RJ (1991) Abundance and feeding of medusae and their potential impact as predators on other zooplankton in Bedford Basin (Nova Scotia, Canada) during spring. Can J Fish Aquat Sci 48:1419-1430

Möller H (1978/79) Significance of coelenterates in relation to plankton organisms. Meeresforsch 27:1-18

Möller H (1980) Population dynamics of Aurelia aurita medusae in Kiel Bight, Germany (FRG). Mar Biol 60:123-128

Otten P (1913) Quantitative Untersuchungen über die Copepoden des Fehmarnbelts und ihre Entwicklungsstadien. Wiss Meeresunters Abt Kiel, NF, 15:249-304

Paffenhöfer GA (1967) Caloric content of larvae of the brine shrimp Artemia salina. Helgoländer wiss Meeresunters $16: 130-135$

Paine RT (1966) Food web complexity and species diversity. Am Nat 100:65-75

Panayotidis P, Papathanassiou E, Siokou-Frangou I, Anagnostaki K, Gotsis-Skretas O (1988) Relationship between the medusae Aurelia aurita Lam. and zooplankton in Elefsis Bay (Saronikos Gulf, Greece). Thalassographika 11 $7-17$

Platt T, Brown V, Irwin B (1969) Caloric content and carbon equivalents of zooplankton biomass. J Fish Res Bd Can 26 $2345-2349$

Purcell JE (1985) Predation on fish eggs and larvae by pelagic cnidarians and ctenophores. Bull mar Sci 37:739-755

This article was submitted to the editor
Purcell JE (1992) Effects of predation by the scyphomedusan Chrysaora quinquecirrha on zooplankton populations in Chesapeake Bay, USA. Mar Ecol Prog Ser 87:65-76

Purcell JE, Cresswell FP, Cargo DG, Kennedy VS (1991) Differential ingestion and digestion of bivalve larvae by the Scyphozoan Chrysaora quinquecrrha and the ctenophore Mnemiopsis leidyi. Biol Bull 180:103-111

Purcell JE, White JR, Roman MR (1994) Predation by gelatious zooplankton and resource limitation as potential controls of Acartia tonsa copepod populations in Chesapeake Bay. Limnol Oceanogr 39:263-278

Schnack SB (1978) Seasonal change of zooplankton in Kiel Bay. III. Calanoid copepods. Kieler Meeresforsch, Sonderh 4:201-209

Schnack SB (1982) The structure of the mouth parts of copepods in Kiel Bay. Meeresforsch 29:89-101

Schneider G (1989a) The common jelly-fish Aurelia aurita: standing stock, excretion and nutrient regeneration in the Kiel Bight, western Baltic. Mar Biol 100:507-514

Schneider G (1989b) Estimation of food demands of Aurelia aurita medusa populations in the Kiel Bight, western Baltic. Ophelia 31:17-27

Schneider G, Behrends G (1994) Population dynamics and the trophic role of Aurelia aurita medusae in the Kiel Bight/ western Baltic. ICES J mar Sci 51:359-367

Smayda TJ (1993) Experimental manipulations of phytoplankton + zooplankton + ctenophore communities, and food web roles of the ctenophore Mnemiopsis leidy1. Comm Meet Int Counc Explor Sea CM-ICES 1993/L:68, p $1-12$

Smetacek V (1980) Zooplankton standing stock, copepod fecal pellets and particulate detritus in Kiel Bight. Estuar coast mar Sci 11:477-490

Sulluan BK, García JR, Klein-MacPhee G (1994) Prey selection by the scyphomedusan predator Aurelia aurita. Mar Biol 121:335-341

Manuscript first received: June 29, 1994 Revised version accepted: May 12, 1995 